\title{
Openism, IPism, Fundamentalism, and Pragmatism
}

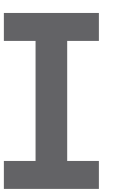
CONSIDER THE $20^{\text {th }}$ century to have ended on Sept. 15, 2008. On that day, U.S. financialservices firm Lehman Brothers filed for bankruptcy protection. This bankruptcy filing, the largest in U.S. history, threatened to turn the economic recession of the 2007-2008 financial crisis into a fullscale economic depression. Only the drastic measures taken by the U.S. government averted that catastrophic possibility. But, in the minds of many people, this event shredded the dogma of capitalism as the ultimate and best economic system, just as the dissolution of the Soviet Union on December 26, 1991, shredded the dogma of communism as the ultimate and best economic system. Of course, just as communists once did, many of today's capitalists blame these failures not on the system itself, but rather on its being "impurely" or "improperly" applied. Yet, history shows that fundamentalist ideas rarely work over the long term, and we are likely destined to move toward the more pragmatic reality of stateregulated free markets. Mark Carney, the governor of the Bank of England, recently asserted, "unchecked market fundamentalism can devour the social capital essential for the longterm dynamism of capitalism itself."

Just as ownership of tangible property was the main battleground over which capitalism and communism fought in the $20^{\text {th }}$ century, ownership of intellectual property is fast becoming the battleground in the $21^{\text {st }}$ century, with today's economy being increasingly driven by large corporations dependent on these intangible assets. At one end, "IP capitalists" view intellectual property as no differ- ent than tangible property. IP capitalists chafe at the limited term of copyright and see nothing wrong with the activity of patent-assertion entities (also known as "patent trolls"), who enforce patent rights in an attempt to collect licensing fees, without manufacturing products or supplying services based upon the underlying patents. At the other end, "IP communists" object to copyright protection and software patents, and even argue that software should be free.

It is regrettable, I believe, that the open access (OA) movement found itself in the IP communist camp. OA advocates unrestricted online access to peer-reviewed scholarly research. On the face of it, this idea is seductively attractive. Who can object to unrestricted access to research? Furthermore, after seeing the price of scholarly publications escalate in the 1990s, open access seemed like a perfect solution; no more escalating subscription fees. But just like any other intellectual property, online publishing has fixed costs, which must be covered. OA advocates often ignore or minimize this issue, but this reality cannot be ignored forever and the dominant business model that has emerged to support OA publishing is "author pays," whereby authors pay article-processing fees to cover publishing costs. This model is not new, but in recent years it has gained a strong foothold in science publishing, both with for-profit commercial publishers and non-profit societies like ACM, which now offers such an option for any and all articles in its Digital Library (DL).

But the move from "reader pays" to "author pays" simply shifts the burden of publishing costs from readers to authors (or their institutions and funders) and it is not yet clear whether this is a more sustainable model than its predecessor. A back-of-the-envelope calculation for a top computerscience department in the U.S. shows a total shift to the open access model would raise the annual costs of DL publishing and access to that department by at least tenfold! Such a move would indeed result in unrestricted online access to scholarly research for the broader community, but is it fair for the costs to be covered by only the creators of the intellectual property and not its consumers? A total move by ACM to the author-pays model would result in only about 500 institutions worldwide supporting the ACM DL, instead the current 2,700 subscribing institutions. Surely, such a significant shift of cost allocation would have major unforeseen consequences.

The U.S. Constitution says "Congress shall have Power...To promote the Progress of Science and useful Arts, by securing for limited Times to Authors and Inventors the exclusive Right to their respective Writings and Discoveries." The goal was pragmatic! Much like the evolution that capitalism is now undergoing since the financial crisis, society needs to take a more pragmatic approach to intellectual property, including the evolution of access models for scholarly information. Revolution and fundamentalism may be appealing when a system no longer works as it once did, but it is important to remain pragmatic or risk collapsing the entire system in an effort to improve it.

Follow me on Facebook, Google+, and Twitter.

Moshe Y. Vardi, EDITOR-IN-CHIEF

Copyright held by author. 